[DOI: 10.24214/jecet.A.9.1.11222]

Juurnal of Enviranmental Science, Computer Science and Engineering \& Technology

An International Peer Review E-3 Journal of Sciences and Technology

Available online at www.jecet.org

Section A: Environmental Science

Research Article

\title{
Hydro- geophysical Investigation of Groundwater Potential in the southeastern part of Iyin-Ekiti, Southwestern Nigeria
}

\author{
Abdu-Raheem, Y. A., Ajayi, C. A., Afolagboye, L. O., *Talabi, A. O. and \\ Adeniran, M. A. \\ Department of Geology, Ekiti State University, P. M. B. 5363, Ado-Ekiti, Nigeria
}

Received: 14 December 2019; Revised: 23 December 2019; Accepted: 03 January 2020

\begin{abstract}
Horizontal profiling and Vertical electrical sounding (VES) resistivity techniques were employed to delineate the viable point(s) for sitting of borehole(s) in the southeastern part of Iyin-Ekiti, southwestern Nigeria. Horizontal profiling was carried out earlier to determine the probable points for the Vertical Electrical Soundings. Ten (10) VES locations were occupied using Schlumberger electrode array. The interpretation of the field data was done employing both partial curve matching and computer iteration. Results of the interpreted data revealed HK, KQ, $\mathrm{HKH}, \mathrm{KH}$ and $\mathrm{H}$ curve types with the $\mathrm{HK}$ curve types dominant representing $50 \%$ of the curves types. Furthermore, four geoelectric sections with varied thicknesses and resistivity were observed. The first layer is the top soil which is composed of dry to wet clayey sand with resistivity ranging from $2114 \Omega \mathrm{m}$ to $6427 \Omega \mathrm{m}$ and a thickness between $0.3 \mathrm{~m}$ and $4 \mathrm{~m}$. This is followed by the partially weathered basement layer with relatively lower resistivity of $1018 \Omega \mathrm{m}$ to $3950 \Omega \mathrm{m}$ which was marginally observed in the VES stations. The third layer is the fresh basement with higher resistivity $(3166 \Omega \mathrm{m}$ to $18493 \Omega \mathrm{m})$ and average thickness of about $15 \mathrm{~m}$. The fourth layer is the weathered/fractured zone with resistivity of $631 \Omega \mathrm{m}$ to $6288 \Omega \mathrm{m}$ and average thickness of $40 \mathrm{~m}$. The fourth geoelectric layer encompassing combination of overburden materials with the fractured basement constitutes the aquiferous zone. The groundwater potential map revealed that the high groundwater potential zone
\end{abstract}


falls into the northwestern part of the study area while the very low to low groundwater potential zones are in the south central areas.

Keywords: Basement terrain, horizontal profiling, aquiferous zone, computer iteration, geo-electric sections.

\section{INTRODUCTION}

Water is life, without water, every living components of may life go into extinction. Water is fundamental to maintain and sustain human life, animal and plant ${ }^{[1]}$. Water is the most important of the basic needs for the survival of human beings. It is a vital component of human body, without which metabolism and other activities in the body cannot be performed.

Groundwater has some advantages over surface water supply and it is usually used as first option community water supplies ${ }^{[2]}$. This preference could be as a result of the fact that surface water sources are prone to contaminations as well as seasonal fluctuation. Groundwater is an important source of freshwater stored in aquifers, it accounts for about $98 \%$ of the world fresh water and is distributed erratically throughout the world. The ever-increasing demands from water users, including municipal, industrial, agricultural and social needs, have further increased the current and continuing shortage supply of potable water in many parts of the world, most especially in parts of the African continent which has greatly warranted the continue search for groundwater.

Groundwater exploration is an expensive venture and as such, some geophysical methods have proven to be appropriate methods that could be used in its exploration in order to reduce cost and to increase the success rate of drilling wells. The use of geophysical methods for groundwater exploration and water quality evaluation has increased dramatically over the last 15 years, especially in developing countries where the individual bears the responsibility of providing water for their daily activities ${ }^{[3]}$.

Electrical resistivity method has proven very viable in groundwater exploration. The electrical resistivity of different geological materials is a function of a number of factors, which include variations in water contents, dissolved ions in water and material that make-up the aquifers which had proved to be helpful in the groundwater exploration techniques [4]. The Schlumberger resistivity method has over the years proved useful in delineation of groundwater and aquifer characteristics due to its better depth $\quad$ resolution 'Atakpo and Akpoborie, ${ }^{[5]}$; Bayewu et al. ${ }^{[6]}$; Odoh, et al. ${ }^{[7]}$; Abubakar, et al. ${ }^{[8]}$.

Iyin-Ekiti is a town situated close to Ado-Ekiti, the Capital of Ekiti State. In view of the close proximity to the State capital, there has been a remarkable influx of people into the town. Given the expansion and population growth in the area, there is the need to proactively map out areas of optimal groundwater supply for exploitation in the study area. This forms the main thrust of this research, which intends to delineate the appropriate aquifer area with a view to producing a blueprint to sitting of high yield boreholes in the area for maximum benefits by the habitants.

\section{LOCATION AND GEOLOGY OF THE STUDY AREA}

The study area is located in Ekiti State, Southwestern Nigeria and lies between Latitudes $7^{0} 39^{1}$ to $7^{0} 40^{1} \mathrm{~N}$ and longitudes $5^{0} 07^{1}$ to $5^{0} 09^{1} \mathrm{E}$ (Fig. 1). Two prominent seasons occur in the area with a long rainy season of March to November and short dry season commencing towards ending of November and terminating in early March. Geologically, the area is made up of Precambrian basement rocks with the lithological units comprising of migmatite and granite gneiss as well as weathered quartzitic 
materials (Fig. 1). The study was constricted to the areas located on a quartzite ridge that is surrounded by granitic and gneissic rocks.

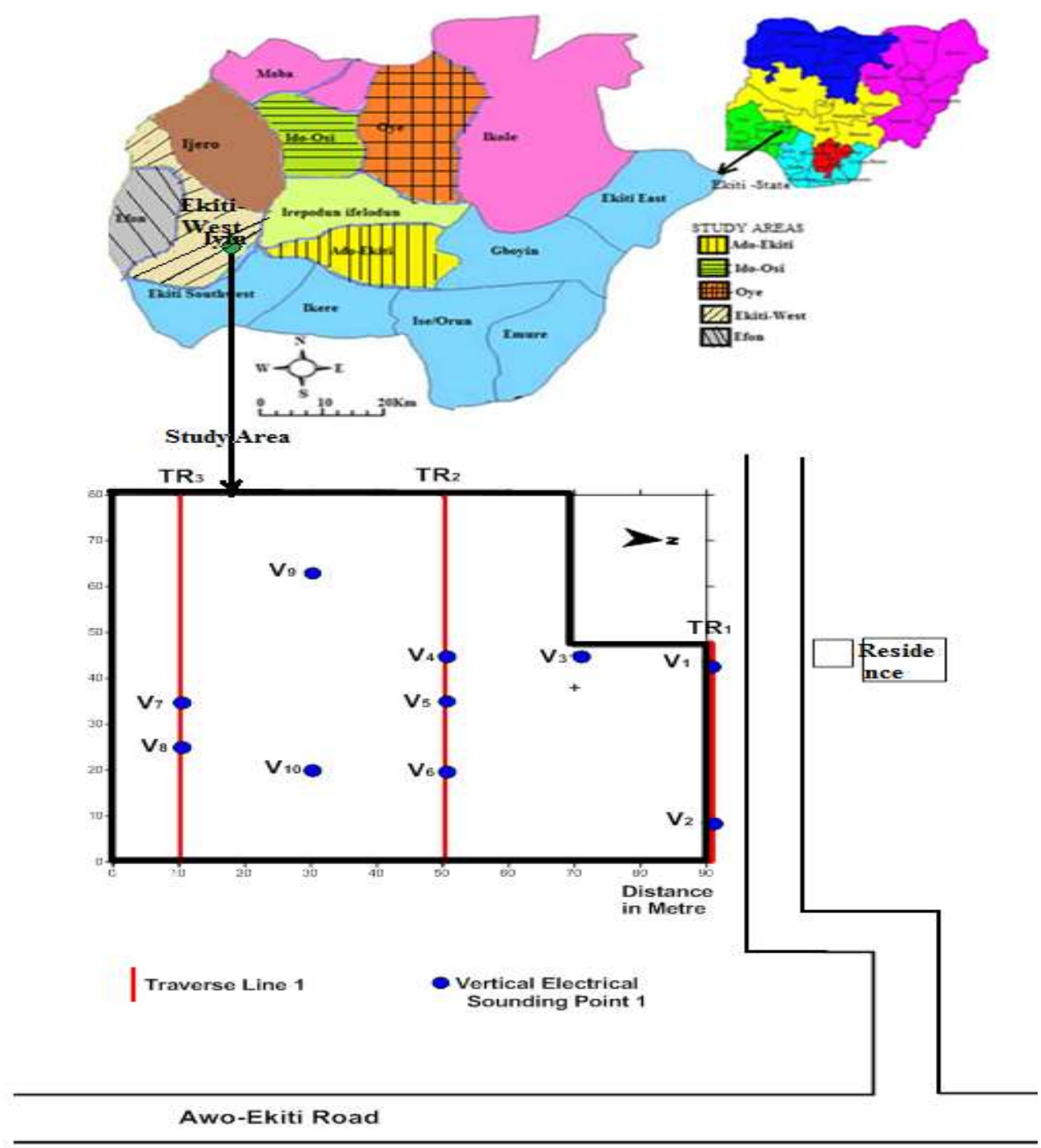

Fig. 1: Location of Study

\section{METHODOLOGY}

The Geophysical investigation was executed using both Horizontal Profiling (HP) and Vertical Electrical Sounding (VES) techniques employing Dipole-Dipole and Schlumberger electrode arrays respectively. The Horizontal Profiling was used for the reconnaissance survey of the area in other to determine the probable locations for Vertical Electrical Soundings. (Fig. 1).

Three traverse lines (Fig. 1) were occupied in the study area. Horizontal profiling was conducted in the west-east direction in order to obtain zones of apparently low resistivity at different depths. These zones of low resistivity values were then used for points of vertical electrical sounding.

A total of ten (10) points were selected for the VES (Fig.1). Three (3) VES points were chosen from traverse $1\left(\mathrm{~V}_{1}, \mathrm{~V}_{2}\right.$ and $\left.\mathrm{V}_{3}\right)$, three also from traverse $2\left(\mathrm{~V}_{4}, \mathrm{~V}_{5}\right.$ and $\left.\mathrm{V}_{6}\right)$, and two (2) from traverse $3\left(\mathrm{~V}_{7}\right.$ and $\mathrm{V}_{8}$ ), while two (2) other sounding points outside the traverse were also picked within the study 
area for proper coverage. The equipment used for the study was the Omega Campus SAS 1000 Resistivity Meter with sets of standard cables, electrodes and modern micro-processor. The electrode separation ranged from 2 to 100 meters to ensure a reasonable depth of probe. The VES field data were processed by both partial curve matching and computer iteration using WinResist. These methods were used to determine the apparent resistivity values, thickness values, degree of saturation, probable lithological units and depth to bedrock or competent material of the area of study. The groundwater potential map was produced through integration of the resistivity and overburden thickness data employing Golden Software Sufer 12.

\section{RESULTS AND DISCUSSION}

Raw field data in respect of the HP and VES are presented in Tables 1 and 2 respectively. Depths of probe along each of the three traverses for the HP ranged from $5.85 \mathrm{~m}$ to $13.65 \mathrm{~m}$ (Figs 2a-2c). At traverse 1 , there was an initial increase in the resistivity value $(1500 \Omega-\mathrm{m}$ to $3500 \Omega-\mathrm{m})$ with depth up to about $45 \mathrm{~m}$ along the east-west direction. Subsequently, a steady decrease in the resistivity values (3500 $\Omega-\mathrm{m}-400 \Omega-\mathrm{m}$ ) with depth from $45 \mathrm{~m}$ to $80 \mathrm{~m}$ along the traverse was observed and the lowest resistivity value was recorded at the tail end of the traverse. Unlike traverse 1(Fig. 2a), there were significant variations in the resistivity values with depth in the HP along traverse 2. The HP along the traverse revealed that the resistivity was apparently low with depth from point $0 \mathrm{~m}$ to about $50 \mathrm{~m}$ having resistivity values ranging from $1500 \Omega-\mathrm{m}-3000 \Omega-\mathrm{m}$. At $55 \mathrm{~m}$ up to $75 \mathrm{~m}$ along the traverse, there was a significant offshoot in the resistivity with values ranging from $3000 \Omega-\mathrm{m}$ to about $70,000 \Omega-\mathrm{m}$ before a gradual decrease down to $3000 \Omega-\mathrm{m}$ from $75 \mathrm{~m}$ along the traverse direction (Fig.2b). It was evident in traverse 3 that the resistivity from $0 \mathrm{~m}$ to $35 \mathrm{~m}$ in east-west direction is low

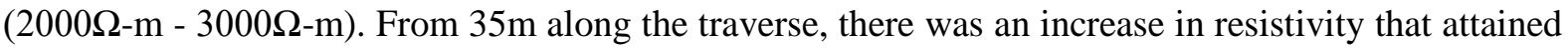
its peak at $55 \mathrm{~m}$ with resistivity of $7000 \Omega$-m before the resistivity gradually decreased (Fig. 2c).
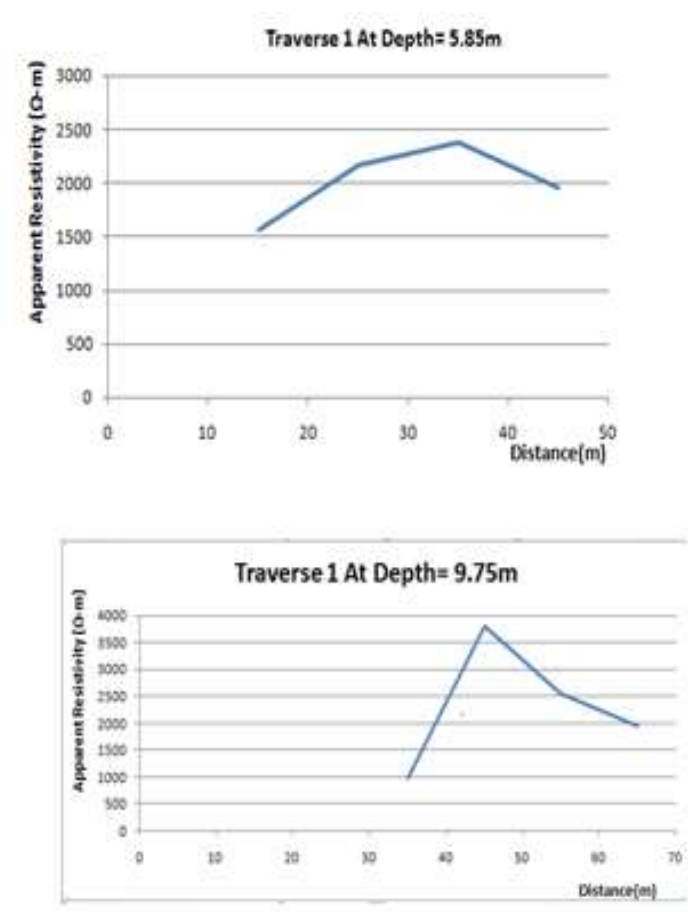
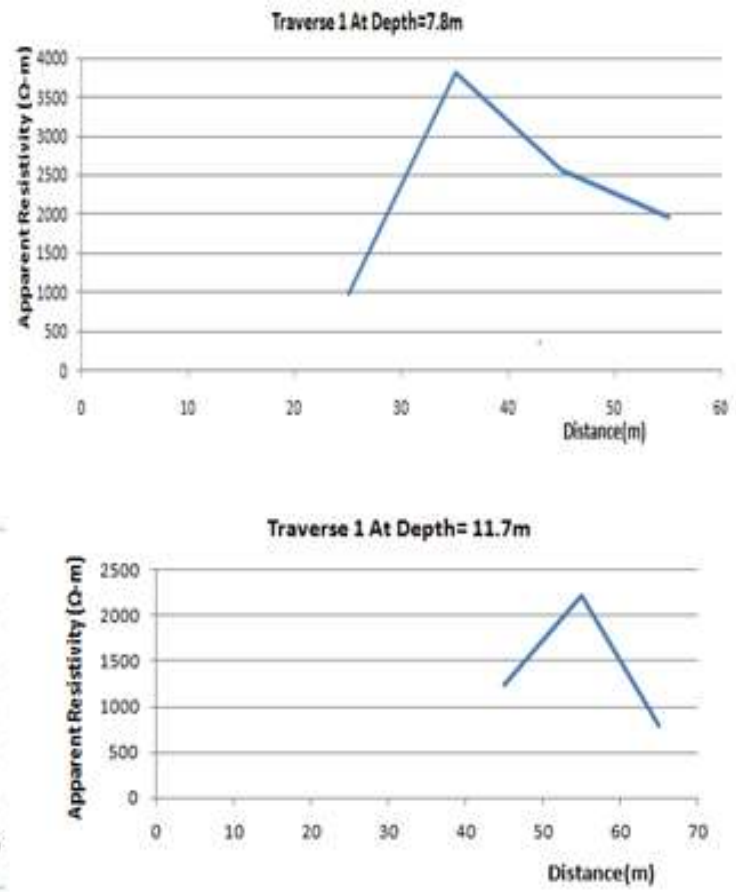

Fig. 2a: Profiles of Apparent resistivity values along Traverse 1 

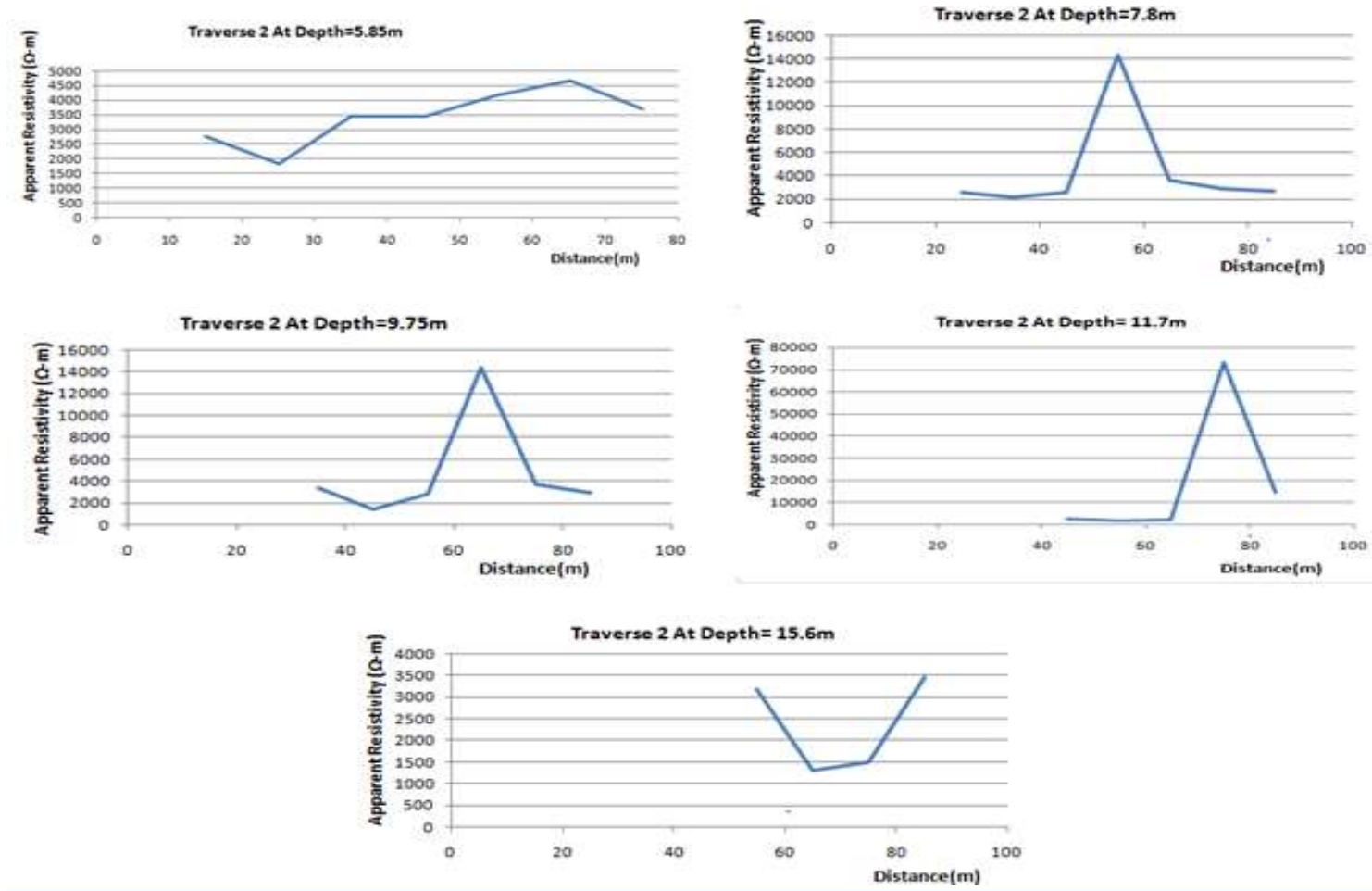

Fig. 2b: Profiles of Apparent resistivity values along Traverse 2
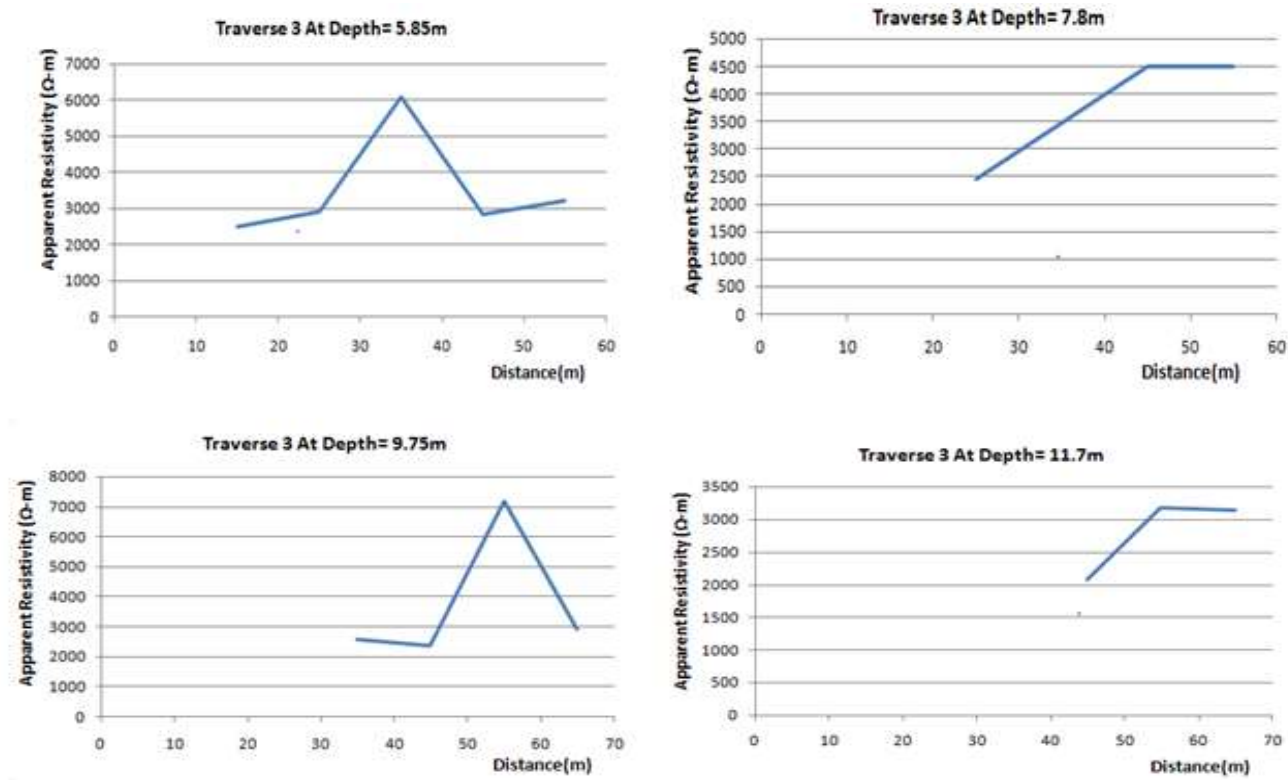

Fig. 2c: Profiles of Apparent resistivity values along Traverse 3

From the horizontal profiles, it was revealed that the areas with low resistivity were from $45 \mathrm{~m}$ to $80 \mathrm{~m}$

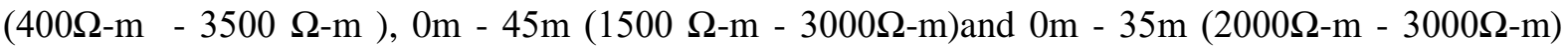
along traverses 1,2 and 3 respectively. As a result, these served as areas of interest for choosing points for vertical electrical soundings. 
Table 1: Raw data sheet for the Resistivity Field Record for Dipole-Dipole carried out in the study area.

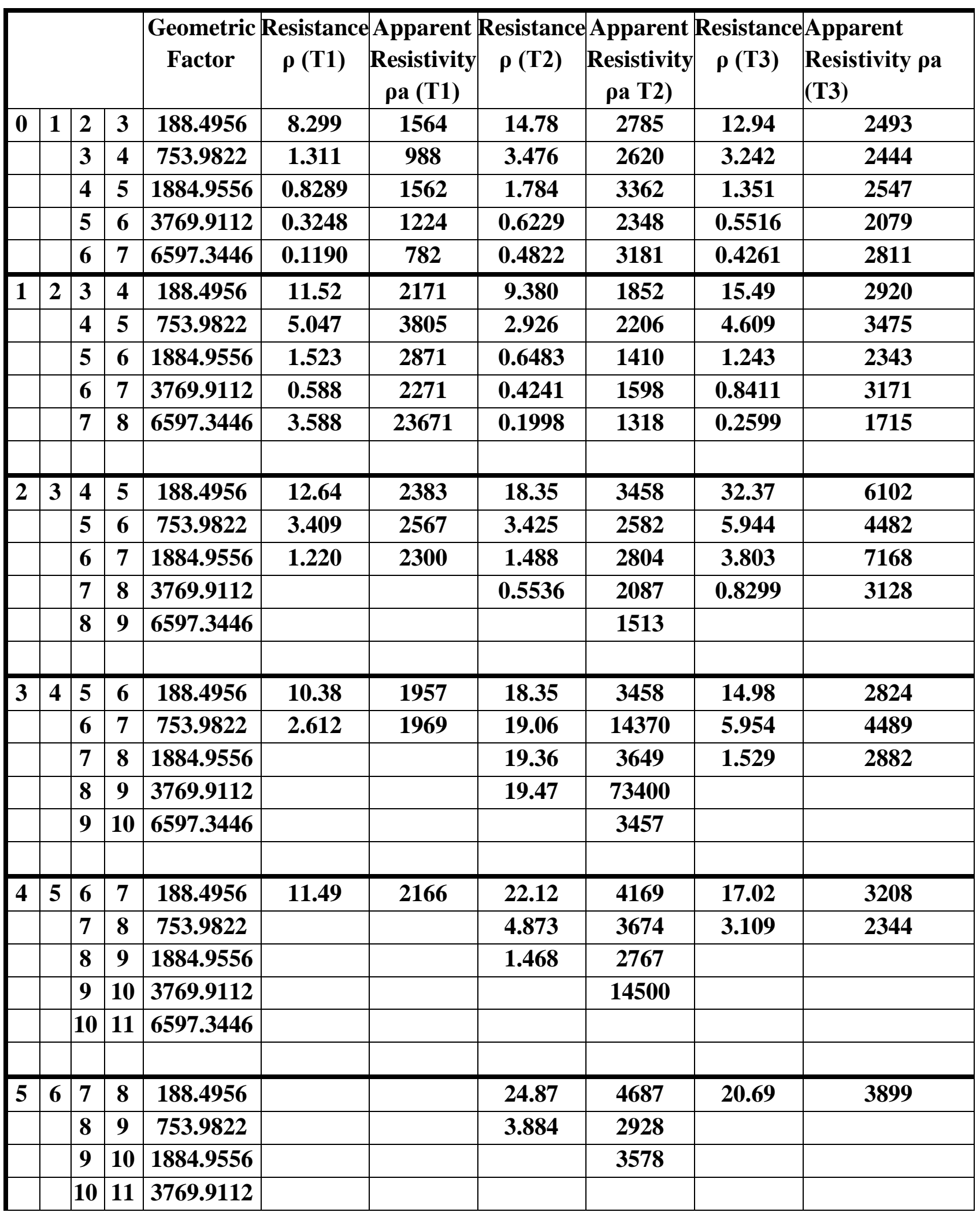


Table 2: Vertical Electrical Sounding Processed Resistivity data acquired on the field.

\begin{tabular}{|c|c|c|c|c|c|c|c|c|c|c|}
\hline $\mathrm{AB} / 2(\mathrm{~m})$ & $\begin{array}{l}\text { VES 1 } \\
\text { pa }\end{array}$ & $\begin{array}{l}\text { VES } 2 \\
\rho a\end{array}$ & 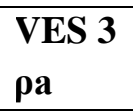 & $\begin{array}{l}\text { VES } 4 \\
\rho a\end{array}$ & $\begin{array}{l}\text { VES } 5 \\
\rho a\end{array}$ & $\begin{array}{l}\text { VES } 6 \\
\rho a\end{array}$ & 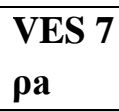 & $\begin{array}{l}\text { VES } 8 \\
\text { pa }\end{array}$ & $\begin{array}{l}\text { VES } 9 \\
\rho a\end{array}$ & $\begin{array}{l}\text { VES 10 } \\
\text { pa }\end{array}$ \\
\hline 1 & 389 & 2869 & 3642 & 2457 & 3243 & 6588 & 4320 & 632 & 3218 & 3742 \\
\hline 2 & 1670 & 1478 & 2228 & 1963 & 3508 & 7883 & 4990 & 5880 & 2113 & 2126 \\
\hline 3 & 1820 & 1339 & 2420 & 2060 & 4556 & 8717 & 5150 & 5770 & 1825 & 2528 \\
\hline 4 & 2674 & 1332 & 2726 & 2613 & 5278 & 9653 & 5555 & 6098 & 1968 & 2813 \\
\hline 6 & 2710 & 1349 & 3574 & 2952 & 6134 & 10093 & 6756 & 6826 & 2673 & 3436 \\
\hline 6 & 3320 & 1441 & 4116 & 3136 & 6676 & 9559 & 6722 & 7299 & 2540 & 3518 \\
\hline 8 & 4262 & 1785 & 3977 & 3549 & 8056 & 9207 & 8136 & 7859 & 3113 & 4116 \\
\hline 12 & 4488 & 2242 & 4165 & 3733 & 9039 & 6225 & 9405 & 9500 & 3994 & 4728 \\
\hline 15 & 4432 & 2325 & 3639 & 3822 & 8786 & 5441 & 8128 & 8786 & 4510 & 5093 \\
\hline 15 & 3803 & 2399 & 3711 & 3897 & 8574 & 5259 & 7206 & 9800 & 4435 & 4982 \\
\hline 25 & 3472 & 1920 & 3813 & 4169 & 6386 & 4000 & 4974 & 7386 & 5113 & 5611 \\
\hline 32 & 2595 & 1930 & 3590 & 3682 & 5001 & 3680 & 4394 & 5853 & 5420 & 5891 \\
\hline 40 & 2571 & 2003 & 3427 & 3524 & 4159 & 3124 & 4380 & 4918 & 5711 & 6311 \\
\hline 40 & 1316 & 2072 & 3408 & 3369 & 4075 & 3207 & 4497 & 4868 & 5850 & 6244 \\
\hline 65 & 800 & 2033 & 3255 & 2595 & 3923 & 3382 & 4125 & 4161 & 6500 & 7510 \\
\hline 100 & & & & & & & & & & \\
\hline
\end{tabular}

4.1 Vertical Electrical Sounding: Results of the processed data obtained from the 10 VES stations across 3traverses were presented in form of table (Table 3) and geo-electric curves (Fig.3) to obtain subsurface lithologic units and the geo-electric properties of the various subsurface layers to foster delineation of aquiferous units in the study area. Geo-electric curves obtained from this study (Fig.3) revealed $\mathrm{HK}, \mathrm{KQ}, \mathrm{HKH}, \mathrm{KH}$ and $\mathrm{H}$ curves. The HK curve type accounted for $50 \%$ of the VES curves, KQ has $20 \%$ while $\mathrm{HKH}, \mathrm{KH}$ and $\mathrm{H}$ accounted for $10 \%$. This shows that the study area loeks appears promising for groundwater development, but the thickness of the productive formations must be put to mind before ascertaining the most appropriate point for the groundwater development.

Table 3: Results of the Vertical Electrical Sounding

\begin{tabular}{l|l|l}
\hline VES Number & Apparent Resistivity Value $(\mathbf{\Omega m})\left(\boldsymbol{\rho}_{\mathbf{1}}\right)\left(\boldsymbol{\rho}_{\mathbf{2}}\right)$ & Thickness $(\mathbf{m}) ;\left(\mathbf{d}_{\mathbf{1}}\right) ;\left(\mathbf{d}_{\mathbf{2}}\right) \ldots . .\left(\mathbf{d}_{\mathbf{n}-\mathbf{1})}\right)$ \\
\hline VES 1 & $(7589),(1321),(8264),(631)$ & $(0.4),(2.5),(12.1)$ \\
VES 2 & $(4013),(1018),(5852),(781),(3062)$ & $(0.6),(3.6),(8.2),(19.2)$ \\
VES 3 & $(5664),(1366),(5166),(2940)$ & $(0.5),(1.5),(9.7)$ \\
VES 4 & $(2114),(6490),(3770),(1348)$ & $(3.0),(8.1),(27.3)$ \\
VES 5 & $(2828),(11734),(1774),(7997)$ & $(1.3),(10.7),(32.6)$ \\
VES 6 & $(6427),(11673),(2811),(9764)$ & $(0.9),(5.4),(49.2)$ \\
VES 7 & $(4273),(18493),(3950),(3612)$ & $(2.1),(5.1),(7.9)$ \\
VES 8 & $(5986),(5513),(12373),(3185)$ & $(1.2),(3.0),(11.5)$ \\
VES 9 & $(3502),(1360),(18721),(6288)$ & $(0.8),(3.5),(6.6)$ \\
VES 10 & $(5049),(1431),(6873)$ & $(0.5),(1.9)$ \\
\hline
\end{tabular}



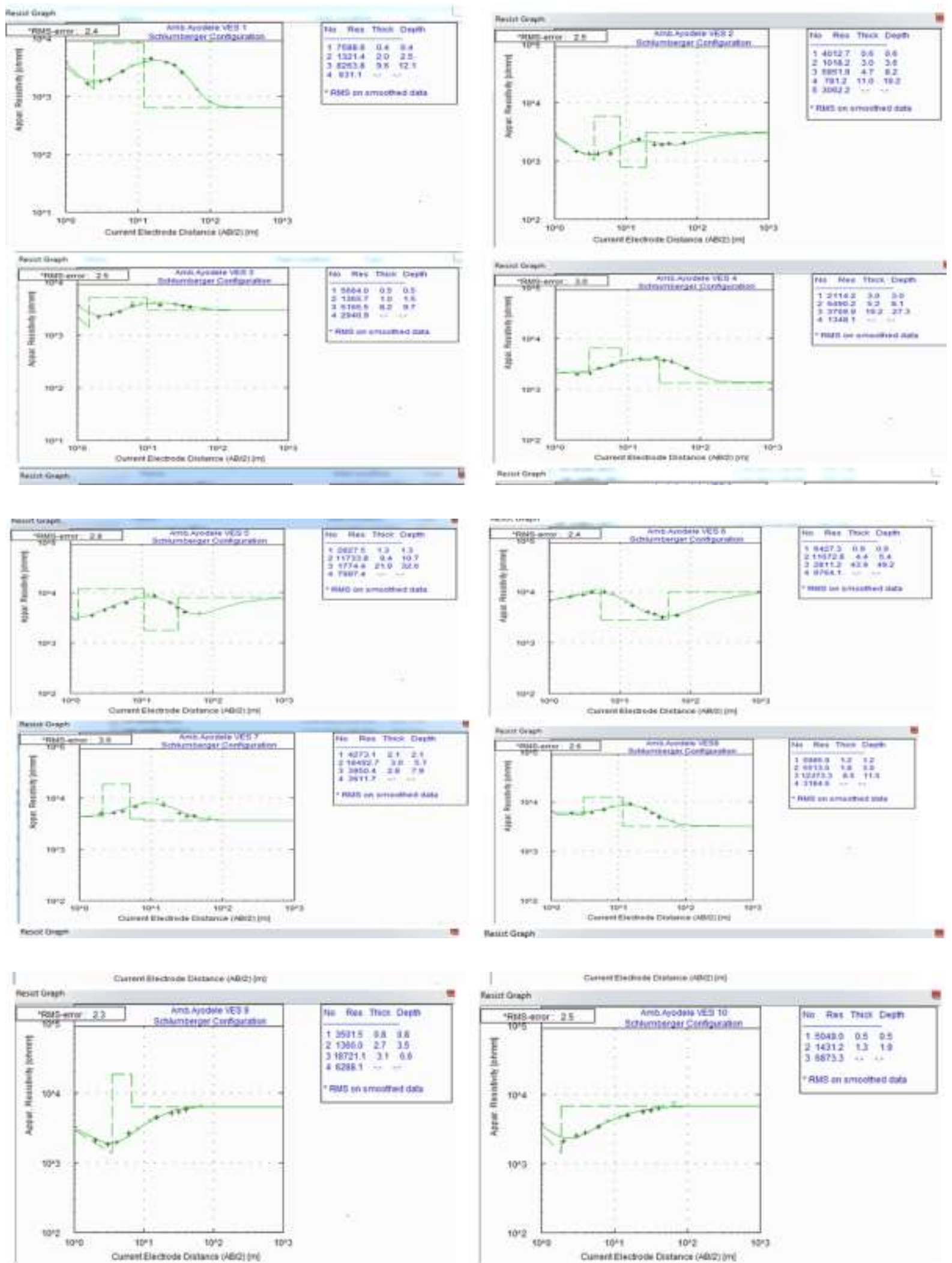

Fig. 3: Curves from Vertical Electrical Sounding Points 1-10 
4.2 Geoelectric Section: The geo-electric sections are drawn across the ten (10) VES stations and are presented in Figs. 4a and $\mathbf{4 b}$. The sections generally show the different subsurface layers and the depth at which they are encountered during the course of investigation in relation to the resistivity value characterizing each layer. The sections generally have 4 layers at the VES points. The first layer is the top soil which is composed of dry to wet clayey sand formation suggested to be of lateritic and quartzitic materials. This layer has resistivity values ranging from $2114 \Omega \mathrm{m}$ to $6427 \Omega \mathrm{m}$ and a thickness between $0.3 \mathrm{~m}$ and $4 \mathrm{~m}$. This layer serves as a zone for evapotranspiration process and not reliable for groundwater accumulation in all the VES stations. The second layer is the partially weathered basements which are not present in all the VES stations. The layer is well or marginally undetectable in the VES stations except VES 5, 6 and 8. The layer has resistivity of $3950 \Omega \mathrm{m}$ to $1018 \Omega \mathrm{m}$ and general thickness of about $2 \mathrm{~m}$ except VES 4 with the highest thickness of about $17 \mathrm{~m}$. The layer is partly expedient for water accumulation and hence, the water in that formation cannot yield water in a sufficient quantity for economical use. The third layer is the fresh basement with resistivity value ranging from $3166 \Omega \mathrm{m}$ to $18493 \Omega \mathrm{m}$ with general thickness of about $10 \mathrm{~m}$ except for VES 10 with high probable thickness exceeding $40 \mathrm{~m}$.

Since this layer is distinguished by low porosity and permeability as indicated by their high resistivity values, it is not a zone of groundwater accumulation. The fourth layer is the highly weathered and fractured zone. The resistivity ranged from $631 \Omega \mathrm{m}$ to $6288 \Omega \mathrm{m}$ with average thickness of $40 \mathrm{~m}$. This layer thickness tends to enhance the accumulation of appreciable and efficient groundwater potential in the area and it is established as the main aquifer zone. Also, the aquifer zone in this study was underlain by the fresh basement which suggests a confined aquifer type which will give rise for convenient flow of water from the aquifer to the earth surface.

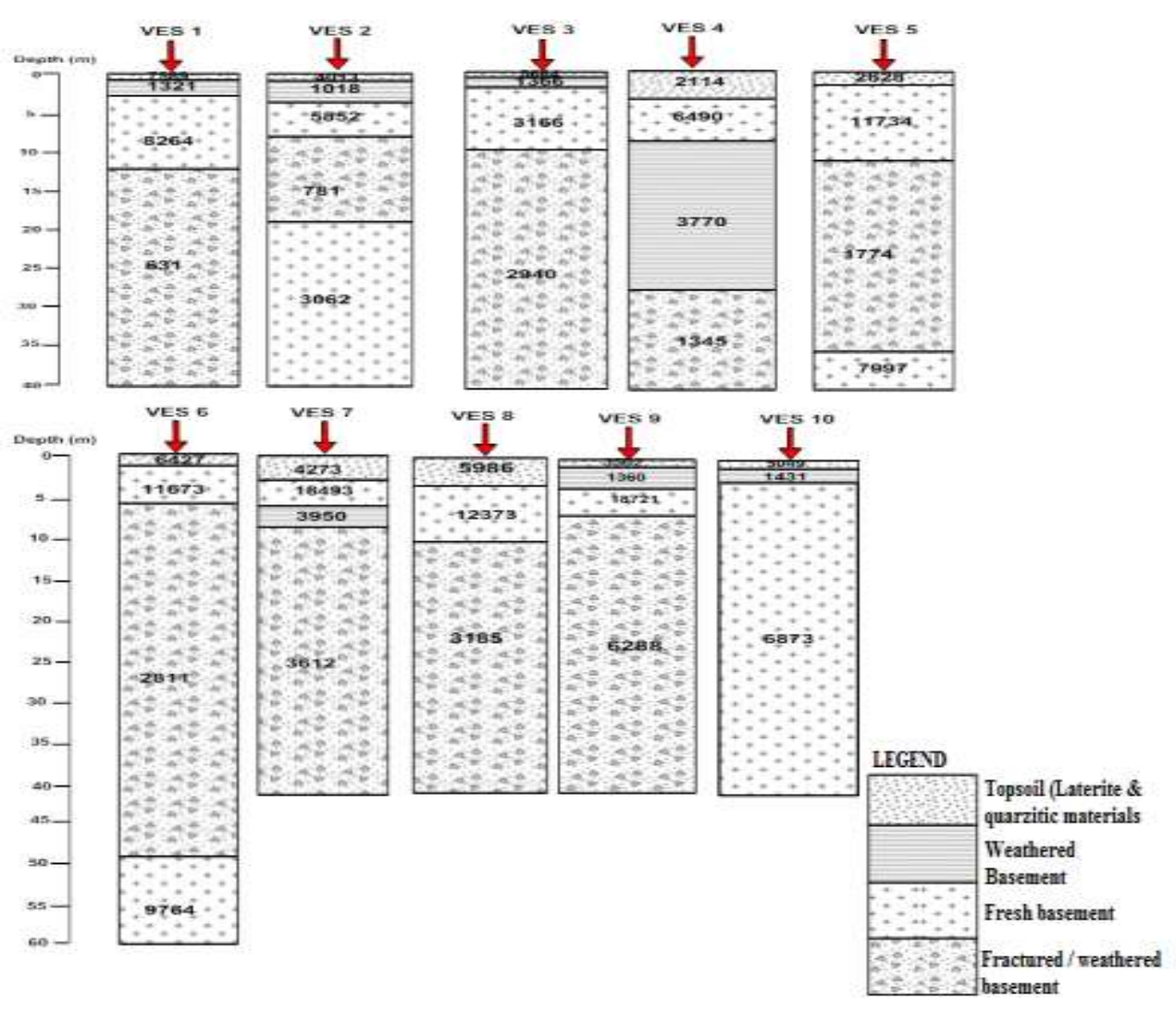

Fig. 4: The Geoelectric Sections of VES points 1-10 within the study area 
4.3. Groundwater Potential of the Study area: The groundwater potential map of the study is presented in Fig.5. The map revealed five different groundwater potential zones (very low potential, low potential, medium potential, high potential and very high potential). The high groundwater potential zone falls into the northwestern part of the study area while the very low to low groundwater potential zones are in the south central areas (Fig.5).

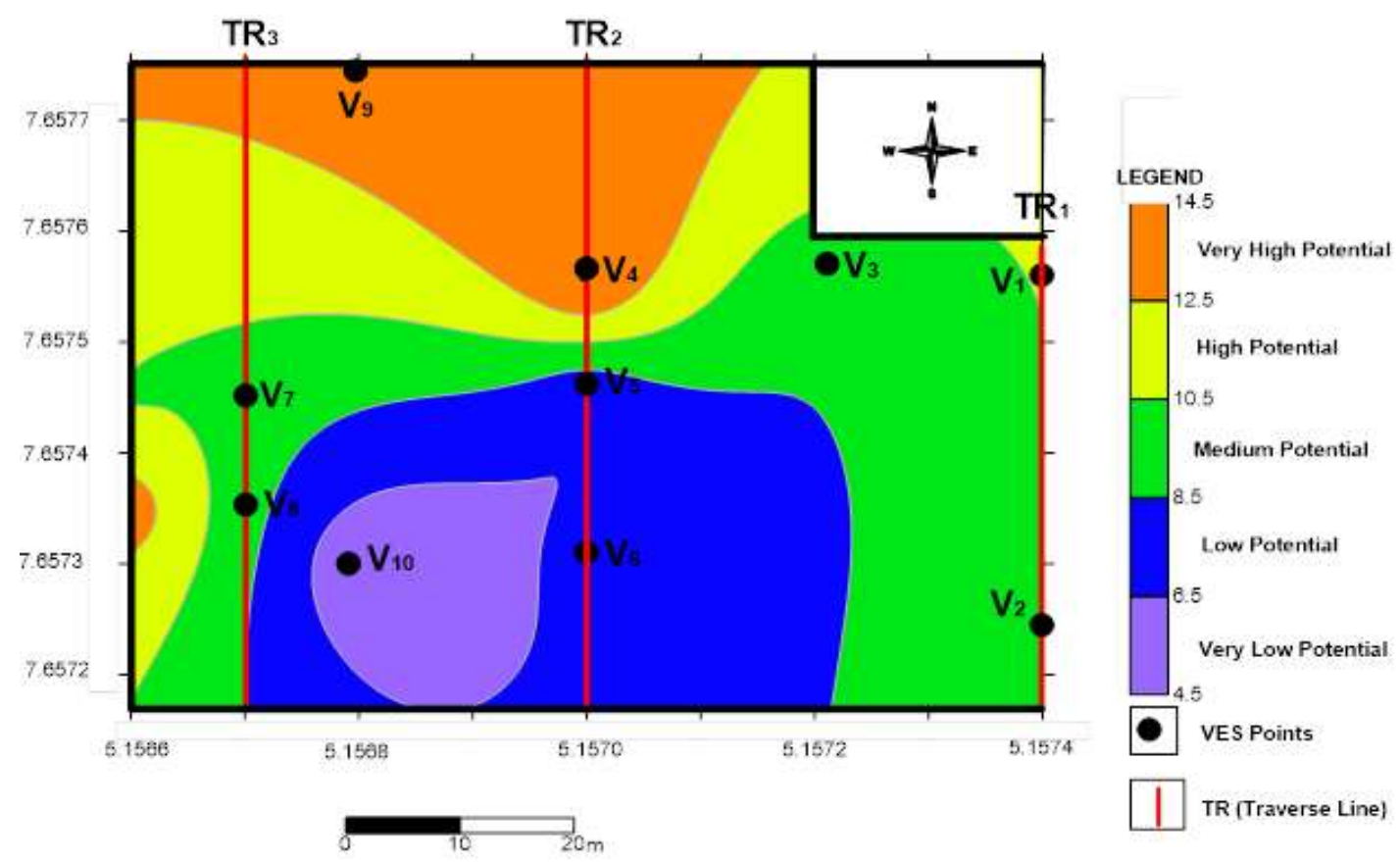

Fig. 5: Groundwater potential map of the study area

\section{CONCLUSION}

Horizontal Profiling and Vertical Electrical Sounding resistivity survey was carried out at the southeastern part of Iyin-Ekiti to establish viable aquiferous zones and point(s) for sitting borehole(s) in the area. Geo-electric curves obtained from this study revealed HK, KQ, HKH, KH and $\mathrm{H}$ curves with the HK curve type dominant accounting for 50\% of the VES curves. Four subsurface layers (Topsoil, weathered basement, fresh basement and fractured/weathered basement) were encountered in this study. The fourth layer (fractured/weathered basement) was the main aquiferous formation of the area with average resistivity value of $1300 \Omega \mathrm{m}$ and thickness greater than $40 \mathrm{~m}$. VES points $1,3,5,6,7,8$ and 9 would give efficient yield of groundwater though, VES 1 seems to be the most suitable station that is saturated with water for borehole drilling due to its apparently low resistivity value of about $600 \Omega \mathrm{m}$. Drilling to depth of $50 \mathrm{~m}$ is essential to penetrate the aquiferous zone.

\section{REFERENCES}

1. V.T. Patil and P.R. Patil, Physicochemical analysis of selected groundwater samples of Amalner town in Jalgaon district, Maharashtra, India. Environmental Journal of Chemistry, 2010, 7, 11-116. 
2. D. Andorful, Groundwater Exploration in Adansi North District of Ghana Using Resistivity Method. A Master thesis submitted to the Department of Physics, Kwame Nkrumah University of Science and Technology, 2013, p(1).

3. W.O. Raji, Review of Electrical and Gravity Methods of Near-Surface Exploration for Groundwater. Nigerian Journal of Technological Development, 2014, 11(2), 31-38.

4. M.I. Imoukhuede and O.E. Ayibawari, Aspects of Geophysical Exploration for Groundwater Using Vertical Electrical Sounding (VES) in Parts of University of Benin, Benin City, Edo State. Journal of Applied Science and Environmental Management. 2014, Vol. 18 (1) 19-25.

5. E.A. Atakpo and A.I. Akpoborie, Geoelectric mapping of Amukpe area of Delta State, Nigeria Journal of Science Environment, 2008, 7: 73-82.

6. O.O. Bayewu, M.O. Oloruntola, G.O. Mosuro and F.G. Watabuni, Groundwater exploration in Ago-Iwoye Area of Southwestern Nigeria, using Very Low Frequency Electromagnetic (VLF-EM) and Electrical Resistivity methods, Int. Journal of Applied Sciences and Engineering Research, 2012, 1(3): 452-462.

7. B.I. Odoh, U.A. Utom and S.O. Nwaeze, Groundwater prospecting in fractured shale aquifer using integrated suite of geophysical method: a case history from Presbyterian Church, KpiriKpiri, Ebonyi State, SE. Nigeria. Journal of Geoscience, 2012, 2(4): 60-65.

8. H.O. Abubakar, W.O. Raji and S. Bayode, Direct current resistivity and very low frequency electromagnetic studies for groundwater development in a Basement Complex area of Nigeria. Science Focus, 2014, 19 (1): 1-10.

\section{* Corresponding Author: Talabi, A. O}

Department of Geology, Ekiti State University, P. M. B. 5363, Ado-Ekiti, Nigeria

Date of publication on line 03.01.2020 